\title{
Fertilizer Nitrogen and Boron Uptake, Storage, and Allocation Vary during the Alternate-bearing Cycle in Pistachio Trees
}

\author{
S.A. Weinbaum, G.A. Picchioni', T.T. Muraoka, L. Ferguson, and P.H. Brown \\ Department of Pomology, University of California, Davis, CA 95616
}

Additional index words. ${ }^{10} \mathrm{~B}$, carbohydrate reserves, fruit tree nutrition, ${ }^{15} \mathrm{~N}$, Pistacia vera, uptake efficiancy

\begin{abstract}
The effects of alternate bearing on recovery and loss of isotonically labeled fertilizer $\mathbf{N}$ and $\mathrm{B}$ and on the accumulation of carbohydrate and $\mathbf{N}$ reserves were assessed in mature 'Kerman' pistachio (Pistacia vera $\mathrm{L}$.) trees. Total recovery of labeled fertilizer $N$ applied once (in late January) was $\approx 60 \%$ greater if applied to trees entering an 'off' than an "on" year, with respect to fruiting. Eleven percent more labeled B was recovered in off- than on-year trees. Five times more $\mathrm{N}$ ( $1 \mathrm{vs.} 0.2 \mathrm{~kg} \mathrm{~N})$ was lost from the tree in fruit and senescent leaflets from on- than off-year trees. In dormant trees, $144 \%$ and $22 \%$ more starch and $N$ reserves, respectively, were present after off than on years. Thus, on-year trees were characterized by a greater reproductive demand for $\mathbf{N}$ and carbohydrates, reduced accumulation of $\mathbf{C}$ and $\mathbf{N}$ (i.e., storage) reserves in perennial tree parts, and reduced recovery of January-applied labeled fertilizer $\mathbf{N}$ than off-year trees. As $B$ is absorbed passively, the higher transpiration that may accompany the $43 \%$ larger leaf area per tree and the probability of increased root growth probably contributes to its increased uptake during off years. The enhanced labeled $N$ recovery in early spring by trees entering their off year preceded fruit and seed development in on-year trees. The differential tree capacity for nutrient uptake in spring may have been conditioned the previous rather than the current year. The increased uptake of labeled $\mathrm{N}$ by trees entering an off year (i.e., emerging from an on year) was associated with lower levels of carbohydrate and $\mathbf{N}$ reserves than for on-year trees that had just completed an off year. Future experimentation should assess the comparative capacity for nutrient uptake by on-and off-year trees at other stages of phenology, e.g., during seed development and postharvest.
\end{abstract}

Alternate bearing-the alternation of high and low crop yearsis widespread among commercially important tree fruit species (Monselise and Goldschmidt, 1982) including pistachio (Crane and Al-Shalan, 1977; Crane and Nelson, 1971, 1972; Crane et al., 1973, 1976; Johnson and Weinbaum, 1987; Takeda et al., 1980). Alternate-bearing studies have addressed a) horticultural means (via thinning, pruning) to regulate cropping and b) effects of crop load on vegetative growth, flowering, and the levels of carbohydrate and $\mathrm{N}$ reserves (Monselise and Goldschmidt, 1982). In contrast, the effect of alternate bearing on patterns of nutrient uptake and use have received scant attention.

Fruit photoassimilate only a small fraction of their $\mathrm{C}$ requirement (Bazzaz et al., 1979). Thus, fruit depend on photoassimilates produced elsewhere. Fruit development may be supported by current photoassimilation or by a redistribution of carbohydrate reserves (principally starch) in shoots, trunk, and roots (Goldschmidt and Golomb, 1982; Loescher et al., 1990; Tromp, 1983). Starch reserves are especially important in early spring before sufficient leaf expansion has taken place to support the net export of photoassimilates (Turgeon, 1989). After the leaves are fully expanded, fruit growth typically occurs at the expense of vegetative growth. The apparent order of priority for $\mathrm{C}$ among metabolic sinks is seeds $>$ fleshy fruit parts $=$ shoot apexes and leaves $>$ cambium > roots > storage (Cannell, 1985; Goldschmidt and Golomb, 1982; Loescher et al., 1990).

Nitrogen uptake requires energy (Marschner, 1986; Salisbury

Received for publication 28 Sept. 1992. Accepted for publication 25 May 1993. We acknowledge the California Pistachio Commission for its financial support. We gratefully acknowledge the assistance of H. Hu, F. Niederholzer, A. Benin, and T. Cristler for tree excavation and fractionation and G. Crisosto for carbohydrate analyses. The cost of publishing this paper was defrayed in part by the payment of page charges. Under postal regulations, this paper therefore must be hereby marked advertisement solely to indicate this fact.

'Present address: U.S. Dept. of Agriculture, ARS, Horticultural Crops Quality Laboratory, 10300 Baltimore Ave., Bldg. 2, Beltsville, MD 20705. and Ross, 1985) and $\mathrm{N}$ influx is independent of transpiration (Schulze and Bloom, 1984). Because roots compete poorly with fruit for assimilates (Cannell, 1985; Goldschmidt and Golomb, 1982; Head, 1969; Loescher et al., 1990; Maggs, 1963; Smith, 1976), a decrease in active nutrient uptake could be anticipated in heavily cropping trees. The impact of alternate bearing on nutrient uptake by trees needs to be assessed in light of increasing public concern over the relationship between fertilization and nitrate leaching, groundwater pollution, and the efficiency of fertilizer $\mathrm{N}$ use (Weinbaum et al., 1992). Carbohydrate deprivation in roots of heavily cropping trees may limit nitrate reduction (Minotti and Jackson, 1970) and uptake (Golomb and Goldschmidt, 1987; Oliveira and Priestley, 1988). Boron uptake is apparently passive, because reduced temperature and the addition of respiratory inhibitors had little effect on B uptake (Bingham, 1970). Uptake of passively absorbed nutrients is influenced by their concentration in the soil solution and the transpirational flux rate of the plant (Barber, 1984; Marschner, 1986).

The objectives of this study were to a) quantify the annual loss of $\mathrm{N}$ in fruit and leaf litter from mature, severely alternate-bearing 'Kerman' pistachio trees; b) determine whether alternate bearing influences tree capacity for $\mathrm{N}$ and $\mathrm{B}$ uptake and the efficiency of nutrient recovery using isotonically labeled $\mathrm{N}$ and $\mathrm{B}$ as tracers; and c) determine the impact of crop alternation on $\mathrm{N}$ and starch reserves in dormant trees.

\section{Materials and Methods}

Plant material and experimental manipulation. Six adjacent, 15-year-old on-year 'Kerman pistachio trees on Pistacia atlantica Desf. rootstock of uniform size were selected at the Wolfskill Experimental Orchard (Winters, Calif.) in 1984. Pistachio trees are highly entrained in California with respect to the alternate-bearing cycle (heavy cropping occurs in even-numbered years). Three of the six on trees were deflorated manually in April 1984 to generate 
off trees under identical environmental conditions. On-year trees yielded an average $45 \mathrm{~kg}$ dry weight (DW) of fruit (hull, shell, and kernel) per tree. Some defloration in April kept off trees completely fruitless. We anticipated that such extreme differences in crop load would provide a sensitive experimental system for testing the influences of alternate bearing on levels of nonstructural carbohydrate and tree capacity for nutrient recovery. The cropping status of the two tree groups differed each year and switched the subsequent year (Table 1).

Effect of alternate bearing on leaflet count, area, and DW per tree. Pistachio leaves are pinnately compound and average five leaflets per leaf. The total number of leaflets per tree was counted each July. Total canopy leaf area and DW (determined after drying for $48 \mathrm{~h}$ at $60 \mathrm{C}$ ) were estimated after a random path sampling each August (Jessen, 1955). Leaflet area was determined using an area meter (Delta-T; Decagon, Pullman, Wash.). Total leaflet areas per tree were calculated as the product of leaflet count and the average area per leaflet.

In 1988-90, five well-exposed spurs were removed from each tree to provide 15 observations at each of five periods for on- and off- year trees. Spurs were taken to the laboratory at the following times: bud swell (early April), mature distillate flowers (mid-April), the beginning of embryo enlargement (late June or early July), fruit maturity (September), and leaf abscission (November). After each sampling, leaflets were dried as previously described, and leaf DW per area $\left(\mathrm{mg} \cdot \mathrm{cm}^{-2}\right)$ was determined using the total leaflet DW and area per spur. Leaflets were stored for subsequent $\mathrm{N}$ analyses. Total leaflet DW per tree at each period was estimated to be the product of individual DW per area (average of five spurs per tree) and total leaflet area per tree. Leaf DW per area did not vary when spurs sampled along a random path were compared with spurs sampled at the tree periphery, presumably because the pistachio canopy is relatively open (data not presented).

Effect of alternate bearing on net annual $N$ removal per tree in fruit and leaf litter and leaf $N$ resorption per tree canopy. The amount of $\mathrm{N}$ loss per tree in senescent leaflets (leaf litter) and the harvested crop was determined in 1986-90. Tissue samples were oven-dried at $60 \mathrm{C}$ and ground to pass a $0.57-\mathrm{mm}$ (30-mesh) screen before $\mathrm{N}$ analysis. Total $\mathrm{N}$ was determinedly a Kjeldahl procedure modified to include nitrate. To analyze labeled $\mathrm{N}$, the ammonium salts were sent to Isotope Services, Los Alamos, N.M., where the ammonia was oxidized to $\mathrm{N}_{2}$ gas before the isotopic composition was determined by mass spectrometry. Atomic percent values were expressed as percentage of $\mathrm{N}$ derived from fertilizer using standard conversions (Cabrera and Kissel, 1989; Hauck and Bremner, 1976). The product of total leaflet count per tree, average leaflet DW, and $\mathrm{N}$ concentration at leaf abscission (as discussed previously) was used to estimate the quantity of $\mathrm{N}$ carried to the orchard floor in leaf litter from each of the six trees.

Each on tree was harvested individually and the crop was weighed. Fruit subsamples $(\approx 100$ fruit/tree) included marketable fruit (fully developed seed, dehisced shell, and loosened hull), blank fruit (parthenocarpic fruit and fruit with aborted seed), and fruit with shriveled, discolored hulls. Marketable fruit comprised $60 \%$ to $70 \%$ of the total harvest weight but contained $85 \% \pm 2 \%$ of the $\mathrm{N}$ in the crop (data not shown). Total $\mathrm{N}$ removal by the harvested fruit was determined as the product of total dry matter yield and $\mathrm{N}$ concentration.

Net leaflet $\mathrm{N}$ resorption per tree canopy was calculated in 1990 as the difference between the total $\mathrm{N}$ content of the foliage between fruit and seed maturation (early September) and natural leaflet abscission in mid-November. Thus, net leaf $\mathrm{N}$ resorption equals the product of total leaflet DW per tree and the difference in leaf $\mathrm{N}$ concentration over the selected interval.

Effect of alternate bearing on the recovery of soil-applied labeled $N$ and $B$. Isotopic $\mathrm{N}$ was supplied to each of the three offand three on-year trees as a $40 \%$ solution (w/v) of ${ }^{15} \mathrm{~N}$-depleted $\left(\mathrm{NH}_{4}\right)_{2} \mathrm{SO}_{4}$ on 26 Jan. 1987. The solution was applied at $1.5 \mathrm{~kg} \mathrm{~N} /$ tree in concentric trenches $25 \mathrm{~cm}$ deep, 1.2 and $1.8 \mathrm{~m}$ from the trunk. The trenches were covered with soil to minimize ammonia volatilization. Leaflet and fruit samples were collected and processed as above before determining the amount of labeled $\mathrm{N}$ removed during 1987-90. After labeled $\mathrm{N}$ was applied, trees were fertilized annually in 1988-90 with nonlabeled $\mathrm{N}$ at the same rate.

On 11 Apr. 1990, isotopic B was applied in a single circular trench $\approx 1 \mathrm{~m}$ from the trunks at $3.3 \mathrm{~g} \mathrm{~B} /$ tree as undissolved, ${ }^{10} \mathrm{~B}$-enriched boric acid $\left[95.91\right.$ atom\% ${ }^{10} \mathrm{~B}$ (Eagle Picher Specialty Products, Quapaw, Okla.)] and the trees were irrigated immediately thereafter. Tissue samples were dried and ground to pass a 30-mesh screen, and 0.5-g subsamples were ashed at 500C for $8 \mathrm{~h}$ and extracted with $1 \mathrm{NHNO}_{3}$. Total $\mathrm{B}$ was determined using the azomethine method (Wolf, 1971), and labeled B (Hanson, 1991) was determined using an inductively-coupled plasma mass spectrometer (Sciex 500; Perkin Elmer, Norwalk, Corm.). A certified isotopic solution (National Institute of Standards and Technology) was used to ensure the accuracy of sample isotopic ratios. Isotopic ratios for unfertilized tissue were obtained from leaf samples collected on 11 Apr. As described for N, leaflet and fruit samples (at harvest) were analyzed to determine total and labeled $\mathrm{B}$ quantities.

Dormant tree excavation and analyses. On 15 Jan. 1991, each tree was excavated and fractionated into roots, 1-year-old (current) wood, trunks, and remaining (canopy) branches. After fresh weights were recorded, the various tree fractions were mechanically chipped. Chipped subsamples were weighed fresh and reweighed after oven drying to constant weight (150 to $250 \mathrm{~g}$ ) to calculate total DWs of

Table 1. Summary of experimental details for six adjacent, mature 'Kerman' pistachio trees between April 1984 and January 1991.

\begin{tabular}{lcccccccc}
\hline \hline Tree & \multicolumn{7}{c}{ Tree cropping status } \\
\cline { 2 - 8 } group & $1984^{z}$ & 1985 & 1986 & $1987^{y}$ & $1988^{x}$ & $1989^{x}$ & $1990^{x, w}$ & $1991^{v}$ \\
\hline A & Off & On & Off & On & Off & On & Off & On \\
B & On & Off & On & Off & On & Off & On & Off \\
\hline
\end{tabular}

${ }^{\mathrm{z}}$ Group A trees were deflorated in April 1984 to generate off-year trees.

${ }^{y}$ All trees were fertilized with labeled $\mathrm{N}$ on $26 \mathrm{Jan} .1987$.

${ }^{\mathrm{x}}$ All trees were fertilized annually with nonlabeled fertilizer $\mathrm{N}$.

${ }^{w}$ All trees were fertilized with labeled B on 11 Apr. 1990. Group A trees were fertilized with labeled $\mathrm{N}$ in their on year and with labeled B in their off year. The opposite was true of Group B trees.

${ }^{v}$ All six trees were excavated on 15 Jan. 1991, fractionated into various tree parts, weighed, and analyzed for nutrients and nonstructural carbohydrates. 
the various tree fractions. The chipped material was ground to pass a 30-mesh screen, and 1-g subsamples were used to determine total $\mathrm{N}$, labeled N, total B, and labeled B. Total labeled N and B recovery was based on the sum of the quantities of labeled $\mathrm{N}$ and $\mathrm{B}$ in fruit and senescent leaflets from the time of label application ( 1987 for $\mathrm{N}$ and 1990 for B) and the residual label in perennial, woody organs (determined after tree excavation in January 1991).

Carbohydrate analyses and effect of alternate bearing on starch content and percentage distribution in dormant trees. Subsamples $(0.3$ to $0.5 \mathrm{~g})$ of the various dormant tree fractions were extracted once for glucose and sucrose (10 min each) in boiling, $80 \%$ ethanol. Starch was hydrolyzed from the ethanol-insoluble material after a 90-min incubation at 55C (Na-acetate buffer, pH 4.8) with amyloglucosidase (grade 2; Sigma, St. Louis). Sugar and starch concentrations (after hydrolysis) were determined using standard enzymatic methods as outlined by Sturgeon (1990). Total tree carbohydrates were calculated using total organ DWs and their corresponding concentrations. One-way analyses of variance were performed using Statview 2 (Abacus Concepts, Berkeley, Calif.).

\section{Results}

Effect of alternate bearing on vegetative growth as indicated by leaflet number, total leaflet area, and leaflet DW per tree. The DW of terminal (vegetative) buds in on- and off-year trees were similar (Table 2). Total $\mathrm{N}$ concentration in buds at budbreak was higher in off- than on-year trees, but $\mathrm{N}$ content per bud did not differ between on- and off-year trees. In contrast, 1 week later (13 Apr.) when pistillate flowers were mature, the leaf mass and leaf $\mathrm{N}$ content per shoot were greater in off- than on-year trees (Table 2). Total leaflet counts, areas, and DWs per tree for off trees averaged 20\%, 43\%, and $44 \%$ more leaflets, total leaflet area, and leaflet DW, respectively, per tree than on trees in 1988-90 (Table 3). Average leaflet area and DW were also greater in off- than in on-year trees, although these differences were not significant at $P<0.05$. Total leaflet area per tree was $>50 \%$ larger in 1989 (tree group B) when they were off than in 1988 when they were on (Table 3). In contrast, leaf area per tree in 1989 was reduced $30 \%$ in trees that were off in 1988 (tree group A) than when they were on. Similar changes in leaflet counts and leaflet DWs per tree were also observed (Table 3).

Table 2. Dry weight (DW), $\mathrm{N}$ concentration, and early spring recovery of labeled $\mathrm{N}$ in terminal vegetative buds at budbreak (7 Apr. 1987) and immature leaves (13 Apr. 1987) after labeled $N$ was applied (26 Jan. 1987) to on- and off-year trees.

\begin{tabular}{|c|c|c|c|c|c|c|}
\hline Organ & $\begin{array}{c}\text { Tree } \\
\text { cropping } \\
\text { status }^{z} \\
(1987)\end{array}$ & DW & $\begin{array}{c}\mathrm{N} \\
(\%)\end{array}$ & $\begin{array}{c}\mathrm{N} \\
\text { content }\end{array}$ & $\begin{array}{c}\text { NDLF }^{y} \\
(\%)\end{array}$ & $\begin{array}{c}\text { Labeled } \\
\mathbf{N}\end{array}$ \\
\hline & & (g/bud) & & (g/bud) & & $\overline{\text { (mg/bud) }}$ \\
\hline \multirow[t]{3}{*}{ Buds (7 Apr.) } & On & $0.74^{w}$ & 4.69 & 0.034 & 0.15 & 49.7 \\
\hline & Off & 0.66 & 5.05 & 0.033 & 0.29 & 95.3 \\
\hline & & $\begin{array}{c}\text { NS } \\
\text { (g/spur) }\end{array}$ & $*$ & $\begin{array}{c}\text { NS } \\
\text { (g/spur) }\end{array}$ & NS & $\begin{array}{c}\mathrm{NS} \\
\text { (mg/spur) }\end{array}$ \\
\hline \multirow[t]{3}{*}{ Leaves (13 Apr.) } & On & 0.91 & 5.16 & 0.047 & 2.31 & 1.09 \\
\hline & Off & 2.38 & 4.57 & 0.108 & 5.40 & 5.84 \\
\hline & & $* * * *$ & $* *$ & $* * * *$ & $* *$ & $* *$ \\
\hline
\end{tabular}

${ }^{2}$ Off-year trees in 1987 cropped heavily in 1986 and vice versa.

'Nitrogen derived from labeled fertilizer, expressed as a percentage of total $\mathrm{N}$.

${ }^{x}$ Each value is the mean of three tree replications.

Ns, $,{ }^{* *}, * * * *$ Nonsignificant at $P \leq 0.05$ or significant at $P \leq 0.05,0.01$, or 0.0001 , according to $\mathrm{F}$ test.

Table 3. Use of random path sampling (August) and total tree leaflet counts to determine the effect of alternate bearing on average leaflet area (LA), dry weight (DW), DW per LA, leaflet DW per tree, and LA per tree over 3 years. ${ }^{2}$

\begin{tabular}{|c|c|c|c|c|c|c|c|c|}
\hline \multirow[b]{2}{*}{$\begin{array}{l}\text { Cropping } \\
\text { status }\end{array}$} & \multirow[b]{2}{*}{$\begin{array}{l}\text { Tree } \\
\text { group }\end{array}$} & \multirow[b]{2}{*}{ Year } & \multicolumn{2}{|c|}{ Leaflet averages } & \multirow[b]{2}{*}{$\begin{array}{c}\mathrm{DW} / \mathrm{LA} \\
\left(\mathrm{mg} \cdot \mathrm{cm}^{-2}\right)\end{array}$} & \multicolumn{3}{|c|}{ Leaflet totals/tree } \\
\hline & & & $\begin{array}{c}\mathrm{LA} \\
\left(\mathrm{cm}^{2}\right)\end{array}$ & $\begin{array}{l}\text { DW } \\
(\mathrm{mg})\end{array}$ & & $\begin{array}{l}\text { Count } \\
(1000 \mathrm{~s})\end{array}$ & $\begin{array}{l}\mathrm{LA}^{y} \\
\left(\mathrm{~m}^{2}\right)\end{array}$ & $\begin{array}{l}\mathrm{DW}^{\mathrm{x}} \\
(\mathrm{kg})\end{array}$ \\
\hline \multirow[t]{4}{*}{ Off } & $\mathrm{A}$ & 1988 & 35.9 & 524 & 14.6 & 39.09 & 140 & 20.4 \\
\hline & B & 1989 & 29.6 & 437 & 14.7 & 56.82 & 167 & 24.5 \\
\hline & A & 1990 & 31.8 & 447 & 13.8 & 54.93 & 173 & 24.1 \\
\hline & & Mean & 32.4 & 469 & 14.4 & 50.28 & 160 & 23.0 \\
\hline \multirow[t]{5}{*}{ On } & B & 1988 & 33.1 & 480 & 14.5 & 32.98 & 109 & 15.8 \\
\hline & A & 1989 & 23.3 & 332 & 14.1 & 40.94 & 95 & 14.2 \\
\hline & B & 1990 & 25.1 & 343 & 13.6 & 53.30 & 133 & 18.1 \\
\hline & & Mean & 27.2 & 385 & 14.1 & 42.40 & 112 & 16.0 \\
\hline & & & NS & NS & NS & NS & $*$ & $* *$ \\
\hline Off : on ratio & & & $1: 19$ & 1.2 & 1.02 & 1.19 & 1.43 & 1.44 \\
\hline
\end{tabular}

${ }^{\mathrm{z}}$ Each value is the mean of three tree replications.

${ }^{y}$ Calculated as the product of leaflet count per tree and average LA (the latter obtained by random path sampling in August).

${ }^{\mathrm{x}}$ Calculated as the product of total leaflet count per tree and average DW per leaflet.

Ns, ${ }^{* * *}$ Nonsignificant at $P \leq 0.05$ or significant at $P \leq 0.05$ or 0.01 , respectively, according to $\mathrm{F}$ test. 
Effect of alternate bearing on leaf $N$ resorption and $N$ removal per tree in harvested fruit and leaf litter. Nitrogen removal associated with the loss of above-ground annual organs (i.e., mature fruit plus senescent leaflets of on-vear trees averaged $400 \%$ more (1.0 vs. $0.2 \mathrm{~kg} \mathrm{~N} /$ tree) than off-year trees (Fig. 1). The $\mathrm{N}$

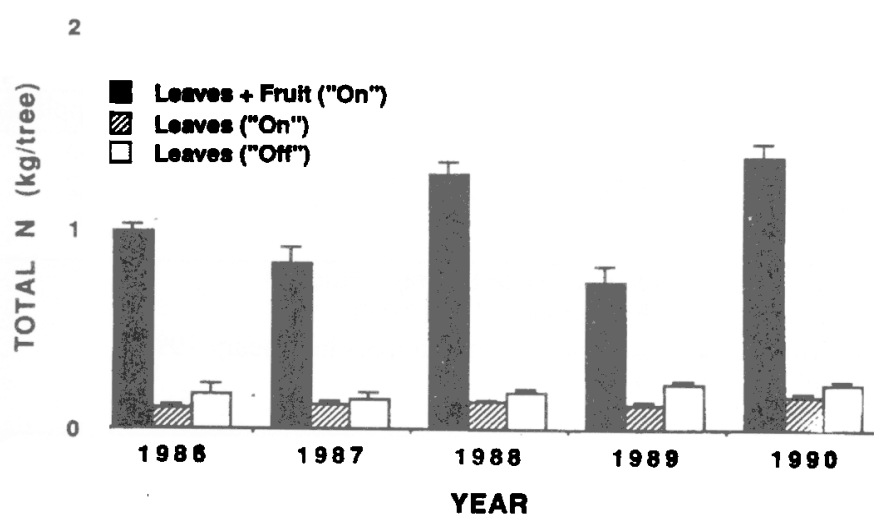

Fig. 1. Annual removal of total $\mathrm{N}$ in senescent leaflets and harvested fruit of mature 'Kerman' pistachio trees. Each value is the mean \pm SE of three tree replications. content of leaf litter (20 Nov.) in on-year trees averaged $15 \%$ less than off-year (fruitless) trees in 1990 (Table 4). This difference resulted from a somewhat greater area per leaflet and higher leaflet counts in off-year trees (Table 3 ).

Our calculations indicated that there was $\approx 50 \%$ more $\mathrm{N}$ in the leaflets of off- than on-year trees (530 vs.310 g, Table 4) in early July. The decrease in leaflet $\mathrm{N}$ concentration between 2 July and 10 Sept. was more conspicuous in on-than off-year trees, presumably because of seed demand for $\mathrm{N}$ in the former. Sixty percent to $70 \%$ net leaflet $\mathrm{N}$ resorption occurred between early July and natural leaf fall in November when calculated based on leaflet $\mathrm{N}$ concentration (calculations based on data in Table 4). The percentage of leaflet $\mathrm{N}$ resorption did not seem to vary consistently between offand on-year trees (data not shown).

Effect of altenate bearing on the amounts and distribution of $D W$, $N$, and starch. Total tree DWs did not differ after on or off years (Table 5). The canopy (branches) constituted nearly $70 \%$ of tree DW followed by roots, trunk, and current wood (1990 shoot growth). Dormant canopy branches contained nearly $60 \%$ of the total tree $\mathrm{N}$ content in on- and off-year trees (Table 5). Off ${ }_{1990}$ trees (i.e., trees analyzed during the dormant season after their off year) contained $22 \%$ more total $\mathrm{N}$ in perennial organs than on ${ }_{1990}$ trees (Table 5).

Table 4. Effect of alternate bearing on leaflet $\mathrm{N}$ concentration, leaflet $\mathrm{N}$ content per tree, ${ }^{\mathrm{z}}$ and net leaflet $\mathrm{N}$ resorption per tree between fruit maturation (10 Sept.) and natural leaf fall (20 Nov.).

\begin{tabular}{|c|c|c|c|c|c|c|c|}
\hline \multirow[b]{4}{*}{$\begin{array}{l}\text { Cropping } \\
\text { status } 1990\end{array}$} & \multicolumn{6}{|c|}{ Sampling stages and dates } & \\
\hline & \multicolumn{2}{|c|}{ Preseed fill (2 July) } & \multicolumn{2}{|c|}{ Fruit maturation (10 Sept.) } & \multicolumn{2}{|c|}{ Leaf fall (20 Nov.) } & \\
\hline & \multicolumn{7}{|c|}{ Leaflet $\mathbf{N}$} \\
\hline & $\begin{array}{c}\text { Concn } \\
(\% \text { dry wt })\end{array}$ & $\begin{array}{l}\text { Content } \\
\text { (g/tree) }\end{array}$ & $\begin{array}{c}\text { Concn } \\
\text { (\% dry wt) }\end{array}$ & $\begin{array}{l}\text { Content } \\
\text { (g/tree) }\end{array}$ & $\begin{array}{c}\text { Concn } \\
\text { (\% dry wt) }\end{array}$ & $\begin{array}{c}\text { Content }^{y} \\
\text { (g/tree) }\end{array}$ & $\begin{array}{c}\text { Net } \\
\text { resorption } \\
(\mathrm{g} / \mathrm{tree})^{\mathrm{x}}\end{array}$ \\
\hline Off & $2.56^{\mathrm{w}}$ & 530 & 2.45 & 586 & 0.97 & 192 & 394 \\
\hline \multirow[t]{2}{*}{ On } & 2.39 & 310 & 2.03 & 287 & 0.97 & 164 & 123 \\
\hline & NS & $* * *$ & $*$ & $* * *$ & NS & $*$ & \\
\hline
\end{tabular}

¿Leaflet $\mathrm{N}$ content ( $\mathrm{g} / \mathrm{tree}$ ) was calculated using leaflet $\mathrm{N}$ concentrations and leaflet biomass per tree (Table 2) determined in early July (preseed fill), early September (harvest), and mid-November (leaf fall).

'Because leaflets were sampled just before natural leaf fall, these values are considered to represent the $\mathrm{N}$ carried to the orchard floor in leaf litter. ${ }^{x}$ Calculated as the difference between leaflet $\mathrm{N}$ content on 10 Sept. and 20 Nov.

wEach value is the mean of three tree replications.

Ns,***,*** Nonsignificant at $P \leq 0.05$ or significant at $P<0.05,0.01$, or 0.001 , respectively, according to $\mathrm{F}$ test.

Table 5. Effect of tree cropping status in 1990 (on or off) on tree dry weight and $\mathrm{N}$ and starch content and percentage distribution in mature, dormant 'Kerman' pistachio trees in January $1991 .{ }^{\mathrm{z}}$

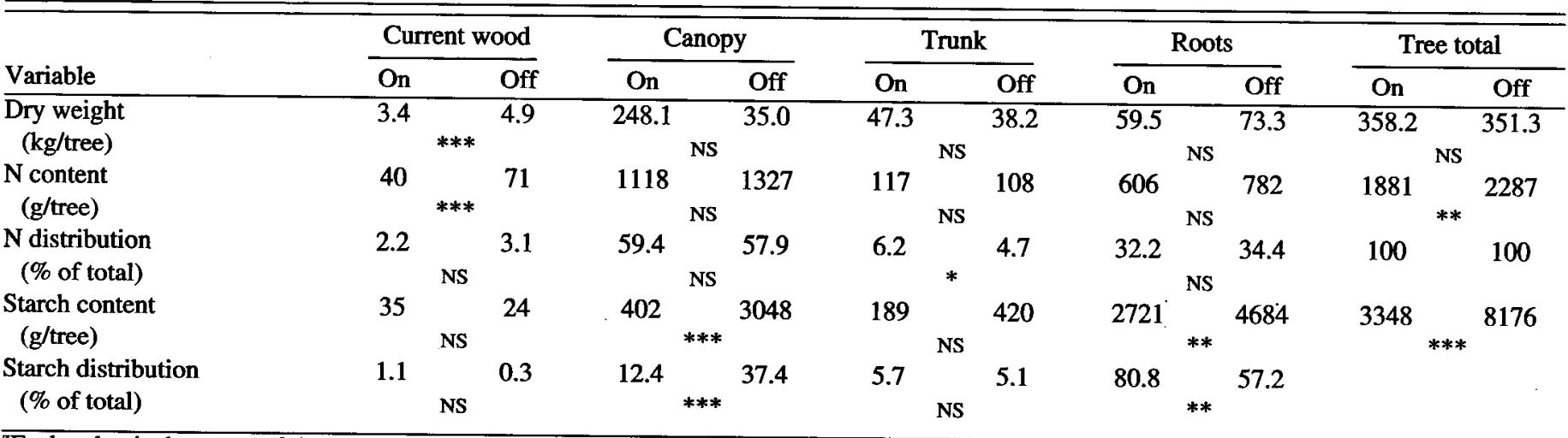

${ }^{\mathrm{z}}$ Each value is the mean of three tree replications.

'Data are characteristic of trees excavated in mid-January; thus, trees had a higher starch content after an off (1990) than an on year. However, because the on year follows an off year, on-year trees start their season with greater reserves than off-year trees.

${ }_{\text {NS }}^{* * * * * *}$ Nonsignificant at $P \leq 0.05$ or significant at $P \leq 0.01$ or 0.001 , respectively, according to $\mathrm{F}$ test. 
There were lower starch concentrations in perennial organs of dormant trees after on than off years. Starch constituted $>80 \%$ of the total nonstructural carbohydrate content in woody organs, and there were no differences between on ${ }_{1990}$ and off ${ }_{1990}$ trees in glucose and sucrose concentration or content (data not presented). Tree starch content averaged $144 \%$ higher after off ${ }_{1990}$ years than on ${ }_{1990}$ years (e.g., $\approx 8.2$ vs. $3.3 \mathrm{~kg}$ total starch/tree, respectively). Similar differences in evergreen fruit tree species have been reported (Goldschmidt and Golomb, 1982; Jones et al., 1975; Smith, 1976).

Starch distribution varied between on- and off-year trees. During dormancy after their on year, trees contained $81 \%$ of total tree starch in their roots, whereas, the roots contained only $57 \%$ of total tree starch during dormancy after their off year (Table 5).

Alternate bearing and tree recovery of isotonically labeled $N$ and $B$. When spring growth resumed, 2.5 months after labeled $\mathrm{N}$ application, the expanding terminal buds in off-year trees tended to accumulate more labeled $\mathrm{N}$ per bud than corresponding buds in on-year trees (Table 2). This tendency, apparent on 7 Apr. 1987, was strengthened over the next week when off-year trees contained five times as much labeled $\mathrm{N}$ in leaves per shoot than on-year trees. There was more labeled $\mathrm{N}$ in the leaves of off- than on-year trees and the percentage of leaf $\mathrm{N}$ derived from recently applied labeled fertilizer was significantly higher in the off- than on-year trees (Table 2).

Trees entering an off year when labeled $\mathrm{N}$ was applied recovered $76 \%$ more labeled $\mathrm{N}$ in senescent leaflets and fruit over 4 years (two alternate-bearing cycles) than trees fertilized with labeled $\mathrm{N}$ at the beginning of their on year (566 vs. $321 \mathrm{~g} /$ tree, respectively; Table 6). Fruit accounted for $70 \%$ to $75 \%$ of the labeled $N$ removed in annual organs in 1987-90 (data not presented).

When trees were excavated (January 1991), canopy branches contained the most labeled $\mathrm{N}$, followed by roots, trunks, and current wood (Fig. 2). After 4 seasons, off ${ }_{1987}$ trees contained $>75 \%$ more labeled $\mathrm{N}$ in perennial tree parts than on $_{1987}$ trees (Fig. 2, Table 6) and had higher labeled $\mathrm{N}(\mathrm{LN})$ to total $\mathrm{N}$ (TN) ratios in all perennial organs $\left[\approx 7 \%\right.$ to $13 \%$ of $\mathrm{LN}: \mathrm{TN}$ in off ${ }_{1987}$ trees compared with $5 \%$ to $8 \% \mathrm{LN}$ : TN for on ${ }_{1987}$ trees (data not shown)].

Total labeled $\mathrm{N}$ recovery was $59 \%$ higher in off ${ }_{1987}$ than in on ${ }_{1987}$ trees. That is, applying labeled $\mathrm{N}$ to trees entering an on year in late January resulted in $\approx 33 \%$ labeled $\mathrm{N}$ recovery, while applying labeled $\mathrm{N}$ to noncropping, off-year trees resulted in $>50 \%$ labeled $\mathrm{N}$ recovery over 4 years (Table 6).

Labeled B recovery in perennial organs, leaflets, and fruit was $<90 \mathrm{mg} /$ tree, or $<3 \%$ of the quantity applied $(3.3 \mathrm{~g})$. Labeled B in leaflets at harvest represented $\approx 40 \%\left(\mathrm{on}_{1990}\right)$ to $50 \%\left(\mathrm{off}_{1990}\right)$ of entire tree totals after one season (Fig. 3). Labeled B removal in petioles was $<39 \%$ of that in leaflets and is included in tree totals. Whereas labeled $\mathrm{N}$ removal by leaflets of on-year trees in 1987 was only $19 \%$ the amount of labeled $\mathrm{N}$ in fruit, leaflets of $\mathrm{on}_{1990}$ trees contained 2.7 times more labeled B than fruit in 1990. Fruit N concentrations (typically $\quad \approx 27 \%$ to $2.5 \%$ of combined hull, shell, and kernel DW at maturity) were of the same order of magnitude as those in leaflets, but fruit B concentrations (weighted average of all fruit portions) were only $57 \%$ to $10 \%$ of leaflet B concentrations. This response is the result of an extreme difference between fruit and leaves in the demand or allocation of $\mathrm{N}$ and $\mathrm{B}$.

The labeled B content of roots was $71 \%$ greater in the off $f_{1990}$ than $0 n_{\text {M }}$ trees (Fig. 3). However, in current wood, canopy, and trunk portions, the quantity of labeled $\mathrm{B}$ did not differ greatly between on- and off-year trees. The labeled B concentration was highest in roots $(2.4 \%$ to $3.2 \%$ of total B), followed by 1990 shoot growth (current wood) $(1.5 \%)$, and canopy branches and trunk $(0.7 \%$ to $0.8 \%$; data not presented). Total labeled $\mathrm{B}$ recovery in all tree
Table 6. Total amount and percentage recovery of the labeled fertilizer $\mathrm{N}$ applied to mature cropping (on-year) and fruitless (off-year) 'Kerman' pistachio trees in January $1987 .^{z}$

\begin{tabular}{|c|c|c|c|c|}
\hline \multirow{3}{*}{$\begin{array}{l}\text { Cropping } \\
\text { status } \\
(1987)\end{array}$} & \multicolumn{4}{|c|}{ Labeled $\mathrm{N}$ recovery } \\
\hline & $\begin{array}{c}\text { Senescent } \\
\text { leaflets }+ \\
\text { fruit }^{y}\end{array}$ & $\begin{array}{l}\text { Weody } \\
\text { organs }\end{array}$ & & otal \\
\hline & (g/tree) & (g/tree) & $\overline{(\mathrm{g} / \text { tree })}$ & (\% of applied) \\
\hline $\mathrm{On}_{1987}$ & 321 & 121 & 422 & 33 \\
\hline $\mathrm{Off}_{1987}^{1987}$ & $\begin{array}{c}566 \\
*\end{array}$ & $\begin{array}{c}216 \\
*\end{array}$ & $\begin{array}{c}793 \\
*\end{array}$ & $\begin{array}{l}52 \\
*\end{array}$ \\
\hline
\end{tabular}

${ }^{\bar{z}}$ Each value is the mean of three tree replications.

${ }^{y}$ Cumulative totals between 1987 and 1990.

Determined after excavating dormant trees in January 1991.

*Significant at $P \leq 0.05$.

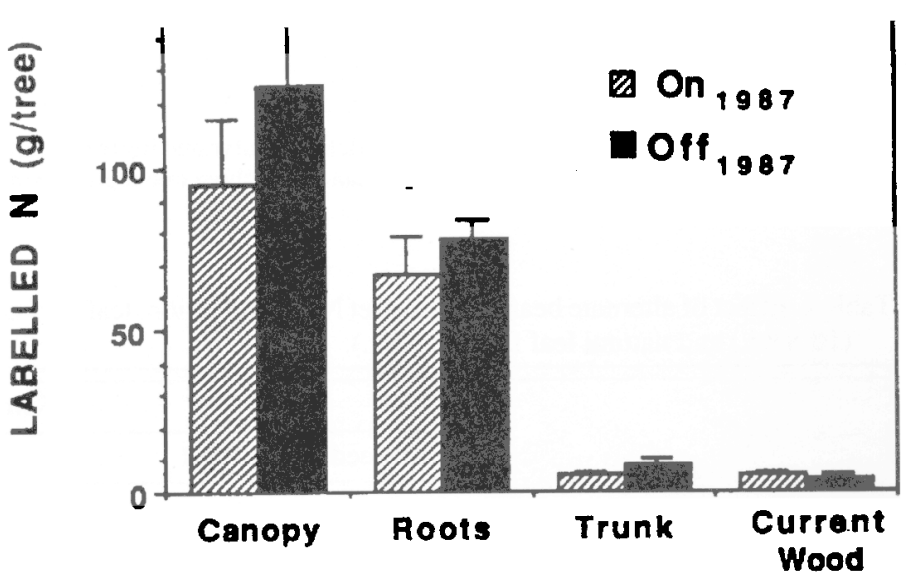

Fig. 2. Recovery of labeled N, applied 26 Jan. 1987, in perennial parts of mature 'Kerman' pistachio trees after tree excavation on $15 \mathrm{Jan} .1991$. On ${ }_{1987}$, trees were on and off ${ }_{1987}$ trees were off during 1987, the year that labeled $\mathrm{N}$ was applied. Each value is the mean \pm SE of three tree replications.

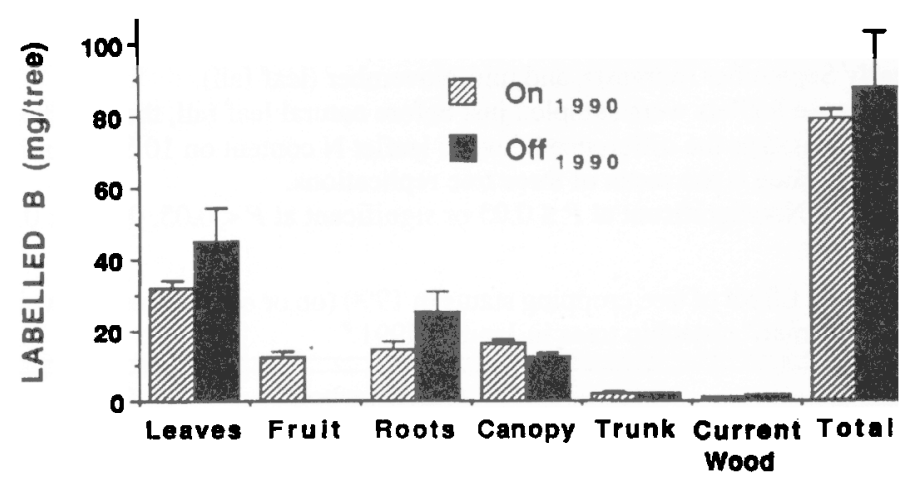

Fig. 3. Recovery of labeled B, applied 11 Apr. 1990, by mature 'Kerman' pistachio trees. Off ${ }_{1990}$ and on on $_{1909}$ refer to tree cropping status in 1990. Each value is the mean \pm SE of three tree replications.

tissues was $11 \%$ greater in off ${ }_{1990}$ than in on $_{1990}$ trees during the year labeled B was applied. The likelihood of greater transpiration by off than on-year trees (off trees have a $43 \%$ greater transpiring leaf surface area, Table 3) may have caused the $11 \%$ increase in labeled B uptake, although the exact importance of this factor can not be determined without measuring tree water use and considering soil B supply characteristics. As a percentage of applied label, 2.7\% and $2.4 \%$ were recovered by off ${ }_{1990}$ and on ${ }_{1990}$ trees, respectively. This finding is consistent with that of labeled $\mathrm{N}$ recovery totals, 
even though Group A trees were fertilized with labeled $\mathrm{N}$ in their on year in 1987 and with labeled B in their off year in 1990 (Table 1) and vice versa. Of the three replicate off ${ }_{1990}$ trees, one contained noticeably less DW in canopy leaves in 1990 (60\% of the remaining replications than the others). This response resulted in $48 \%$ less labeled $\mathrm{B}$ recovery than the average of the other two trees. We estimate that the total labeled B recovery of off ${ }_{1990}$ trees would have been $29 \%$ greater than on $_{1990}$ trees if the atypical replicate had been discarded.

The within-tree total B distribution differed considerably from that of labeled B. Canopy branches of off ${ }_{1990}$ and on ${ }_{1990}$ trees contained $61 \%$ and $69 \%$, respectively, of total tree B in perennial organs (data not shown), but roots off ${ }_{1990}$ and on $n_{1990}$ trees contained $60 \%$ and $42 \%$, respectively, of total labeled B (Fig. 3). This difference may indicate that recently absorbed $\mathrm{B}$ is sequestered in roots after uptake and is redistributed later to other parts of the tree. Because most B is thought to be in cell walls and associated with sugar and phenolic compounds with cis-diol hydroxyl groupings (Dugger, 1983), any cropping effect on the relative proportions of these compounds in roots could influence B binding. The availability of B complexation sites could influence B uptake.

\section{Discussion}

Woody perennials differ from herbaceous annual species in ways other than longevity and the production of secondary vascular tissue. Much documentation supports the concept that tree experiences in the current year, such as crop load and drought, influence tree performance in subsequent years. Alternate bearing gives testimony to the reality of carryover effects. That is, heavy cropping (the on year) is linked functionally with the midsummer abscission of inflorescence buds and conditions the tree to enter the subsequent year with relatively few inflorescences and, as a result, experience an off year (Crane and Nelson, 1971). Trees entering their on year (having just experienced an off year) have greater overwinter carbohydrate and $\mathrm{N}$ reserves (Table 4) than trees entering their off year. One manifestation of greater tree reserves entering an on year is longer, early season (April to mid-May) shoot extension than is characteristic of off-year trees (i.e., trees with lower reserves, coming off of an on year) (Crane and A1-Shalan, 1977).

We hypothesized that nutrient uptake would be resource-limited in on-year trees. That is, the dominance of fruit as a metabolic sink would limit a) carbohydrate transport to roots, b) root growth, and c) energy-dependent nutrient uptake. Although our data substantiated reduced labeled $\mathrm{N}$ recovery (applied in late January) by onrelative to off-year trees (Table 6), our interpretation of the phenomenon is less clear. Greater labeled $\mathrm{N}$ recovery in spring by off- year trees (Table 6) occurred despite reduced carbohydrate and $\mathrm{N}$ reserves relative to trees entering their on year (Table 5). Thus, reduced carbohydrate and $\mathrm{N}$ reserves did not seem to limit early season labeled $\mathrm{N}$ uptake relative to trees entering their on year. Differences between on- and off-year trees in starch content may have been even greater during seed fill, the period of maximum resource demand by the fruit. The greater recovery by off-year trees of labeled fertilizer $\mathrm{N}$ applied during late January cannot be ascribed to the negative impact of current-year fruit development on root growth and activity because the enhanced labeled $\mathrm{N}$ uptake by off- relative to on-year trees preceded the significant period of fruit and seed development in on-year trees. More likely, the greater spring labeled $\mathrm{N}$ recovery by off-year trees, i.e., after on years, was conditioned previously, i.e., during the on year. To our knowledge, this is the first report of the impact of alternate bearing on the capacity for nutrient uptake by mature, field-grown trees.

Starch concentrations of various tree parts are frequently reported (Crane and A1-Shalan, 1977), but few studies have addressed the size, i.e., the content, of the nonstructural carbohydrate pool in mature trees (Goldschmidt and Golomb, 1982; Murneek, 1942). The starch content of mature dormant pistachio trees was $\approx 2.5$ times larger after an off than an on year $(8.2 \mathrm{vs} .3 .3 \mathrm{~kg} /$ tree, respectively). The availability of a larger pool of metabolic reserves in trees that recently completed an off year (and are entering anon year) may be an integral part of the alternate-bearing cycle.

Although our data are not sufficient to develop a $\mathrm{C}$ budget for off- vs. on-year pistachio trees, an estimated removal of $20 \mathrm{~kg} \mathrm{C} /$ tree in the fruit of on-year trees $(45 \mathrm{~kg} \mathrm{DW}$ of fruit per tree multiplied by an estimated $45 \% \mathrm{C}$ per unit DW) coupled with a reduced leaf area per tree averaging 43\% (Table 3) is consistent with the imbalance between $\mathrm{C}$ demand and relative capacity for $\mathrm{C}$ assimilation in on-year trees.

Trees analyzed during the dormant season after their off year contained $22 \%$ more total $\mathrm{N}$ in perennial organs than trees after their on year. Presumably, the greater tree $\mathrm{N}$ content includes a greater amount of storage $\mathrm{N}$ that accumulates in late summer and fall as a result of soil $\mathrm{N}$ uptake and leaf $\mathrm{N}$ resorption (Millard and Neilsen, 1989; Millard and Roe, 1992; Millard and Thomson, 1989; Taylor, 1967) and is cycled into new growth the following spring. Thus, the larger accumulation of storage $\mathrm{N}$ in off-year pistachio trees may be considered an $\mathrm{N}$ buffer for use during on years (0' Kennedy and Titus, 1979) when $\mathrm{N}$ use by annual organs (fruit and leaf litter) is four times greater than it is in off years (Fig. 1). This conspicuously greater removal of $\mathrm{N}$ in annual organs of on-year trees was accompanied by a $37 \%$ lower recovery of soil-applied, labeled fertilizer $\mathrm{N}$ (Table 6 ) and $\approx 45 \%$ less leaf $\mathrm{N}$ resorption per tree (Table 6). Off-year trees recovered $\approx 350 \mathrm{~g}$ more of soil-applied, labeled fertilizer $\mathrm{N}$ than on-year trees (Table 6). Also, the greater leaf biomass in off-year trees (Table 4) was associated with an estimated $270 \mathrm{~g}$ (394 vs. $123 \mathrm{~g} /$ tree) higher net leaf $\mathrm{N}$ resorption than in on-year trees (Table 4). Decreases in leaf $\mathrm{N}$ concentration and $\mathrm{N}$ mass per unit leaf area during leaf senescence have been well documented (Chabot and Hicks, 1982; Spencer and Titus, 1972; Titus and Kang, 1982), but no studies have attempted to estimate the relative contribution of leaf $\mathrm{N}$ resorption to the entire within-tree pool of storage $\mathrm{N}$. The greater net leaf $\mathrm{N}$ resorption ( $270 \mathrm{~g} \mathrm{~N} /$ tree in 1990) in off- than on-year trees (Table 4) accounts for $>60 \%$ of the difference in total tree $\mathrm{N}$ content (406 g; Table 5) measured after tree excavation in January 1991.

The use of isotonically labeled fertilizer $\mathrm{N}$ allowed us to measure fertilizer $\mathrm{N}$ recovery directly. Although the fate of labeled fertilizer $\mathrm{N}$ not recovered by the trees was not determined, an inverse relationship between tree labeled $\mathrm{N}$ recovery and the likelihood of loss (leaching, denitrification) is anticipated.

Fertilizer $\mathrm{N}$ use efficiency (NUE) has been defined as the amount of fertilizer $\mathrm{N}$ recovered by the plant divided by the total amount of fertilizer $\mathrm{N}$ applied. NUE values between $25 \%$ and $50 \%$ are considered typical for crop plants (Weinbaum et al., 1992). Site-specific soil and climatic variables and fertilizer and irrigation application methods and rates influence NUE. Our data indicate convincingly that alternate bearing influences a tree's capacity to recover fertilizer $\mathrm{N}$ and, thus, its NUE. Off-year 'Kerman' pistachio trees recovered nearly $60 \%$ more labeled fertilizer $\mathrm{N}$ than onyear trees (782 vs. $493 \mathrm{~g}$, Table 6). The relative difference in fertilizer $\mathrm{N}$ recovery between on- and off-year trees reported in this study is probably more significant than the absolute percentages of labeled fertilizer $\mathrm{N}$ recovery, which are influenced by site-specific, 
management, and environmental variables (Weinbaum et al., 1992; Yamaguchi, 1991).

The apparent recovery of fertilizer $\mathrm{N}$ by plants is typically lower when isotonically labeled $\mathrm{N}$ is used (the direct method) than when the indirect or difference method is used (Jansson and Persson, 1982; Jenkinson et al., 1985). That is, labeled fertilizer $\mathrm{N}$ recovery by plants is less than the difference in $\mathrm{N}$ content between unfertilized and fertilized plants. Jenkinson et al. (1985) suggested that applying fertilizer $\mathrm{N}$ stimulates a net rnineralization of soil $\mathrm{N}$, with subsequent consumption of the mineralized $\mathrm{N}$ by the crop-the socalled "priming" effect. Another explanation is that labeled fertilizer $\mathrm{N}$ will be immobilized in the organic soil $\mathrm{N}$ fraction when nontagged soil $\mathrm{N}$ is mineralized. By taking up isotonically diluted pool $\mathrm{N}$, the plant will contain less tagged $\mathrm{N}$ and more nontagged $\mathrm{N}$ (Jansson and Persson, 1982; Jenkinson et al., 1985).

Fertilizer $\mathrm{N}$ recovery seemed to occur primarily during the year (and perhaps within several months) of fertilizer application, with very little influx of labeled $\mathrm{N}$ in subsequent years. Immobilization of labeled $\mathrm{N}$ in soil $\mathrm{N}$ pools that are not accessible to tree roots for uptake, $\mathrm{N}$ losses by leaching, denitrification, or both, and dilution of labeled $\mathrm{N}$ in soluble soil $\mathrm{N}$ pools resulting from the annual application of nonlabeled fertilizer N (Weinbaum et al., 1987) may contribute. Field-crop studies also indicate that, although $20 \%$ to $40 \%$ of the fertilizer applied may remain in the field after a single cropping, recovery of that residual fertilizer $\mathrm{N}$ in the soil by subsequent crops is estimated to be only $3 \%$ to $4 \%$ of the amount applied initially (Yamaguchi, 1991). Thus, to expect significant fertilizer $\mathrm{N}$ recovery by trees in subsequent years seems unwarranted, and trees should not be fertilized when their nutrient uptake capacity is limited. More detailed studies are needed, however, to determine how changes in nutrient uptake capacity vary over the alternate-bearing cycle. We do not know, for example, how the capacity for fertilizer $\mathrm{N}$ uptake varies during specific periods; i.e., preseed fill, seed fill, and postharvest, in on years.

\section{Literature Cited}

Barber, S.A. 1984. Soil nutrient bioavailability, a mechanistic approach. Wiley, New York.

Bazzaz, F.A., R.W. Carlson, and J.L. Harper. 1979. Contribution to reproductive effect by photosynthesis of flowers and fruits. Nature 279:554-555.

Bingham, F.T., A. Elseewi, and J.J. Oertli. 1970. Characteristics of boron absorption by excised barley roots. Soil Sci. Soc. Amer. Proc. 34:613617.

Cabrera, M.L. and D.E. Kissel. 1989. Review and simplification of calculations in ${ }^{15} \mathrm{~N}$ tracer studies. Fert. Res. 20: 11-15.

Cannell, M.G.R. 1985. Dry matter partitioning in tree crops, p. 160-193. In: M.G.R. Cannell and J.E. Jackson (eds.). Attributes of trees as crop plants. Inst. of Terrestrial Ecol., Midlothian, Scotland.

Chabot, B.F. and D.J. Hicks. 1982. The ecology of leaf life spans. Annu. Rev. Ecol. Systematic 13:229-259.

Crane, J.C. and I. A1-Shalan. 1977. Carbohydrate and nitrogen levels in pistachio branches as related to shoot extension and yield. J. Amer. Soc. Hort. Sci. 102:396-399.

Crane, J. C., I. A1-Shalan, and R.M. Carlson. 1973. Abscission of pistachio inflorescence buds as affected by leaf area and number of nuts. J. Amer. Soc. Hort. Sci. 98:591-592.

Crane, J. C., P.B. Catlin, and I. A1-Shalan. 1976. Carbohydrate levels in the pistachio as related to alternate bearing. J. Amer. Soc. Hort. Sci. 101:371-374.

Crane, J.C. and M.M. Nelson. 1971. The unusual mechanism of alternate bearing in the pistachio. HortScience 6:489-490.

Crane, J.C. and M.M. Nelson. 1972. Effects of crop load, girdling, and auxin application on alternate bearing of the pistachio. J. Amer. Soc. Hort. Sci. 97:337-339.
Dugger, W.M. 1983. Boron in plant metabolism, p. 626-650. In: A. Läuchli and R.L. Vieleski (eds.). Encyclopedia of plant physiology. new series. Springer-Verlag, New York.

Goldschmidt, E.E. and A. Golomb. 1982. The carbohydrate balance of alternate-bearing citrus trees and the significance of reserves for flowering and fruiting. J. Amer. Soc. Hort. Sci. 107:206-208.

Golomb, A. and E.E. Goldschmidt. 1987. Mineral nutrient balance and impairment of the nitrate-reducing system in alternate-bearing 'Wilking' mandarin trees. J. Amer. Soc. Hort. Sci. 112:397-401.

Hanson, E.J. 1991. Movement of boron out of tree fruit leaves. HortScience 26:271-273.

Hauck, R.D. and J.M. Bremner. 1976. Use of tracers for soil and fertilizer nitrogen research. In: N.C. Brady (cd.). Adv. Agron. 28:219-266.

Head, G.C. 1969. The effects of fruiting and defoliation on seasonal trends in new root production on apple trees. J. Hort. Sci. 44: 175-181.

Jansson, S.L. 1958. Tracer studies on nitrogen transformations in soil with special attention to mineralization-immobilization relationships. Ann. Royal Agr. College of Sweden 24: 101-361.

Jansson, S.L. and J. Persson. 1985. Mineralization and immobilization of soil nitrogen, p. 229-252. In: F.J. Stevenson (cd.). Nitrogen in agricultural soils. Amer. Soc. of Agron., Madison, Wis.

Jenkinson, D. S., R.H. Fox, and J.H. Rayner. 1985. Interactions between fertilizer nitrogen and soil N- the so-called "priming" effect. J. Soil Sci. $36: 425-444$.

Jessen, R.J. 1955. Determining the fruit count on a tree by a randomized branch sampling. Biometrics $11: 99-109$.

Johnson, R.S. and S.A. Weinbaum. 1987. Variation in the tree size, yield, cropping efficiency, and alternate bearing among 'Kerman' pistachio trees. J. Amer. Soc. Hort. Sci. 112:942-945.

Jones, W. W., T.W. Embleton, and C.W. Coggins, Jr. 1975. Starch content of roots of 'Kinnow' mandarin trees bearing fruit in alternate years. HortScience 10:514.

Loescher, W. H., T. McCamant, and J.D. Keller. 1990. Carbohydrate reserves, translocation, and storage in woody plant roots. HortScience 25:274-281.

Maggs, D.H. 1963. The reduction in growth of apple trees brought about by fruiting. J. Hort. Sci. 38:199-128.

Marschner, H. 1986. Mineral nutrition of higher plants. Academic Press, London.

Millard, P. and G.H. Neilsen. 1989. The influence of nitrogen supply on the uptake and remobilization of stored $\mathrm{N}$ for the seasonal growth of apple trees. Ann. Bot. 63:301-309.

Millard, P. and M.F. Proe. 1992. Storage and internal cycling of nitrogen in relation to seasonal growth of Sitka spruce. Tree Physiol. 10:33-43.

Millard, P. and C.M. Thomson. 1989. The effect of the autumn senescence of leaves on the internal cycling of nitrogen for the spring growth of apple trees. J. Expt. Bot. 40: 1285-1290.

Minotti, P.L. and W.A. Jackson. 1970. Nitrate reduction in the roots and shoots of wheat seedlings. Planta 95:36-44.

Monselise, S.P. and E.E. Goldschmidt. 1982. Alternate bearing in fruit trees. Hort. Rev. 4:128-173.

Murneek, A.E. 1942. Quantitative distribution of nitrogen and carbohydrates in apple trees. Physiol. Plant. 12:594-648.

O'Kennedy, B.T. and J.S. Titus. 1979. Isolation and mobilization of storage proteins from apple shoot bark. Physiol. Plant. 45:419-444.

Oliveira, C.M. and C.A. Priestley. 1988. Carbohydrate reserves in deciduous fruit trees. Hort. Rev. 10:403-430.

Salisbury, F.B. and C.W. Ross. 1985. Plant physiology. Wadsworth, Belmont, Calif. p. 114-134.

Schulze, E.-D. and A.J. Bloom. 1984. Relationship between mineral nitrogen influx and transpiration in radish and tomato. Plant Physiol. 76:827-828.

Smith, P.F. 1976. Collapse of 'Murcott' tangerine trees. J. Amer. SW. Hort. Sci. 101:23-25.

Spencer, P.W. and J.S. Titus. 1972. Biochemical and enzymatic changes in apple leaf tissue during autumnal senescence. Plant Physiol. 49:746-750.

Sturgeon, R.J. 1990. Monosaccharides, p. 1-37. In: P.M. Dey (cd.). Methods in plant biochemistry. vol. 2. Carbohydrates. Academic Press, New York. 
Takeda, F., K. Ryugo, and J.C. Crane. 1980. Translocation and distribution of ${ }^{14} \mathrm{C}$-photosynthates in bearing and nonbearing pistachio branches. J. Amer. Soc. Hort. Sci. 105:642-644.

Taylor, B.K. 1967. Storage and mobilization of nitrogen in fruit trees: A review. J. Austral. Inst. Agr. Sci. 33:23-29.

Titus, J.S. and S.-M. Kang. 1982. Nitrogen metabolism, translocation, and recycling in apple trees. Hort. Rev. 4:204-246.

Tromp, J. 1983. Nutrient reserves in roots of fruit trees, in particular carbohydrates and nitrogen. Plant and Soil 71:401-413.

Turgeon, R. 1989. The sink-source transition in leaves. Annu. Rev. Plant Physiol. Plant Mol. Biol. 40: 119-138.
Weinbaum, S.A., R.S. Johnson, and T.M. DeJong. 1992. Causes and consequences of overfertilization in orchards. HortTechnology 2: 112-121.

Weinbaum, S. A., I. Klein, and T.T. Muraoka. 1987. Use of nitrogen isotopes and a light-textured soil to assess annual contributions of nitrogen from soil and storage pools in mature almond trees. J. Amer. Soc. Hort. Sci. 112:526-529.

Wolf, B. 1971. The determination of boron in soil extracts, plant materials, composts, matures, water and nutrient solutions. Commun. Soil Sci. Plant Anal. 2:363-374.

Yamaguchi, J. 1991. Fertilizer-nitrogen absorption determined by the ${ }^{15} \mathrm{~N}$ isotopic and difference methods. Jpn. Agr. Res. Quarterly 25:93-100. 